The Factors Contributing to the pH Quality of Wastewater: A Case Study of Beverage Manufacturer in Malaysia.

Mashitah Mohamed Esa, Faizatul Akmam Amiruddin, Veera Pandiyan Kaliani Sundram and Juwita Sari Mohd Rosley

To Link this Article: http://dx.doi.org/10.6007/IJARBSS/v11-i5/9705 DOI:10.6007/IJARBSS/v11-i5/8835

Received: 21 March 2021, Revised: 24 April 2021, Accepted: 07 May 2021

Published Online: 18 May 2021

In-Text Citation: (Esa et al., 2021)

To Cite this Article: Esa, M. M., Amiruddin, F. A., Sundram, V. P. K., \& Rosley, J. S. M. (2021). The Factors Contributing to the $\mathrm{pH}$ Quality of Wastewater: A Case Study of Beverage Manufacturer in Malaysia. International Journal of Academic Research in Business and Social Sciences, 11(5), 336-345.

Copyright: (c) 2021 The Author(s)

Published by Human Resource Management Academic Research Society (www.hrmars.com) This article is published under the Creative Commons Attribution (CC BY 4.0) license. Anyone may reproduce, distribute, translate and create derivative works of this article (for both commercial and non-commercial purposes), subject to full attribution to the original publication and authors. The full terms of this license may be seen at: http://creativecommons.org/licences/by/4.0/legalcode

Vol. 11, No. 5, 2021, Pg. 336 - 345

Full Terms \& Conditions of access and use can be found at http://hrmars.com/index.php/pages/detail/publication-ethics 


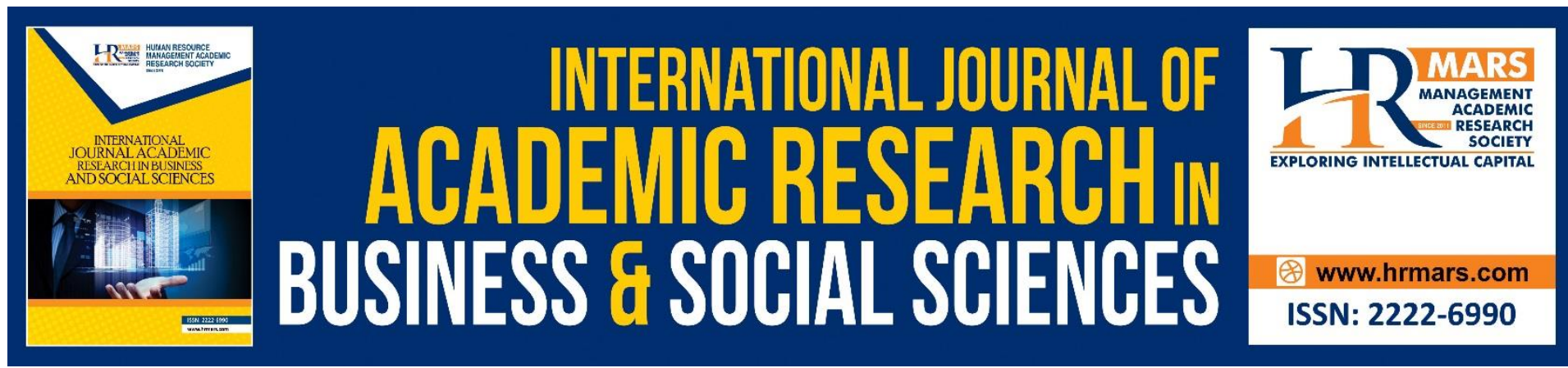

\title{
The Factors Contributing to the pH Quality of Wastewater: A Case Study of Beverage Manufacturer in Malaysia.
}

\author{
Mashitah Mohamed Esa, Faizatul Akmam Amiruddin, Veera \\ Pandiyan Kaliani Sundram and Juwita Sari Mohd Rosley \\ Faculty of Business and Management, Universiti Teknologi MARA, Cawangan Selangor, \\ Kampus Puncak Alam, Malaysia \\ Email: mashitah9803@uitm.edu.my
}

\begin{abstract}
The beverage manufacturer consumed a large amount of clean water in the production process. From the clean water usage in the production process, the manufacturer needs to monitor wastewater discharge from the beverage production. Each beverage company is obligated to monitor wastewater discharge compliance with the Department of Environment (DOE) 's regulations. The quality of wastewater discharge must meet the DOE's pH level requirements, ranging from $\mathrm{pH} 5.5$ to $\mathrm{pH} 9.5$. Therefore, this study aims to identify the factor contributing to the $\mathrm{pH}$ quality of wastewater and understand the effects of wastewater. As beverage manufacturers produce different types of products such as drinking juice, herbal energy drink, carbonated sports drink, tea, and coffee, the quality of wastewater discharge will differ. The study was conducted through an interview to explore in-depth understanding about beverage production and identify the factor related to wastewater quality. Five respondents were selected to participate in the study, and these respondents were of different departments and positions involved in both the production process and wastewater management department. The observation was also made to record and monitor the reading of $\mathrm{pH}$ level for few cycle. A few factors were identified in contributing to the $\mathrm{pH}$ quality of wastewater such as types of production and methods used to read the $\mathrm{pH}$ level.
\end{abstract}

Keywords: Ph Quality, Sustainability, Wastewater, Wastewater Management

\section{Introduction}

The concept of quality is not only focused on the end product. The quality elements should cover from the selection of raw materials to the disposal of the waste from production process. For beverage manufacturers, they do not only focus on the choice of raw materials for their production, but at the same time, they also need to monitor wastewater discharge from the beverage production. Each beverage company is obligated to monitor wastewater discharge in compliance with the Malaysia Department of Environment (DOE) 's regulations. 
The quality of wastewater discharge must meet the DOE's $\mathrm{pH}$ level requirements, which is in a range of between pH5.5 to pH9.5.

This study aims (1) to identify the factor contributing to the $\mathrm{pH}$ quality of wastewater and (2) understand the effects of wastewater. As beverage manufacturers produce different types of products such as drinking juice, herbal energy drink, carbonated sports drink, tea, and coffee, hence, the quality of wastewater discharge will differ.

The study was conducted through an interview to explore in-depth understanding about beverage production and identify the factor related to wastewater quality. Five respondents were selected to participate in the study and these respondents were of different departments and positions involved in both the production process and wastewater management department. An observation was also made to record and monitor the reading of $\mathrm{pH}$ level for few cycle. A few factors were identified in contributing to the $\mathrm{pH}$ quality of wastewater such as types of production and methods used to read the $\mathrm{pH}$ level. This study will provide the best practices in the production process to ensure the $\mathrm{pH}$ level for wastewater discharge complies with DOE's standards.

\section{Literature Review \\ Wastewater}

Wastewater is a by-product of industrial processing (Rinkesh, 2019). Wastewater contains a number of pollutants and contaminants including plant nutrients, pathogenic microorganisms, heavy metals, organic pollutants and micro pollutants which can cause health and environmental problems (Connor, 2015). The quality of wastewater discharge is different depending on the material and equipment used during the production process. In order to comply with DOE regulations, water used in the process must be treated before all the water leaves the plant. The treatment of wastewater is also different based on the material used during production process. Wastewater treatment is a process, which is done on the wastewater to change its quality for drinking or other suitable purposes. Wastewater treatment takes place in wastewater treatment plants, which should be designed under different circumstances (Jasim and Aziz, 2020). These facilities are designed to remove/decrease conventional pollution parameters (BOD5, COD, total suspended solids and nutrients) from the wastewater stream (Edokpayi, Odiyo and Durowoju, 2017). Wastewater pollution load depends on the type of product being processed and the process and equipment used, while the common characteristic is the strong organic content (Valta et al, 2015). Most factories continuously generate large amounts of wastewater that are released to the aquatic environment after treatment.

\section{Effects of Wastewater}

\section{Environment}

The release of untreated and ill-treated wastewater into water courses has a short and long term effect on the environment and human health (Edokpayi, Odiyo and Durowoju, 2017). In most cultures, wastewater is disposed of in the streets and near population centres creating serious impacts on public health and the environment (Lofrano and Brown, 2010). Villarin and Merel (2020) explained that wastewater is a significant environmental and public health concern of which the management is a constant challenge since antiquity". It can have detrimental and permanent effects on the ecosystem if wastewater is pumped into rivers before it is properly handled. Toxic compounds in the effluent can seriously disrupt aquatic 
ecosystems. Wastewater's most immediate effect on the ecosystem is that it leads to the contamination and deterioration of natural environments and animals living in those habitats. Chemical compounds from ill-treated water waste may find their ways into the soil which causes the soil to yield fewer crops at slower rate and affects the food supply chain. In certain cases, untreated wastewater can elevate the temperature of water, which further disrupts the ecosystem.

\section{Health}

Nowadays, wastewater management is still an issue and strategies have evolved in order to protect public health while limiting the ecological impact on receiving waters (Villarain and Merel, 2020). Untreated wastewater can spread disease and contaminate drinking water sources. Toxins in industrial waste are the major cause of immune suppression, reproductive failure and acute poisoning. Infectious diseases like cholera and typhoid fever and other diseases such as gastroenteritis, diarrhea, vomiting, skin and kidney problem are spreading through polluted water (Haseena,2017). Bacteria are the most common pathogens usually found in treated wastewater and cause several infections and diseases particularly towards young, pregnant, immune-compromised and aged people (Edokpayi, Odiyo and Durowoju, 2017). According to Haseena (2017), different industrial effluent that is drained out to the river without treatment and poor wastewater treatment is the major cause of water pollution. He further elaborated that hazardous materials discharged from the industries are responsible for surface and ground water contamination and some of the toxic metals may reduce the quality of water.

\section{Compliance to regulation}

The Malaysian government guarantees that the industry complies entirely with the regulatory enforcement of wastewater. Under Environmental Quality (Industrial Effluent) Regulations 2009, industrial effluent means any waste in the form of liquid or wastewater generated from manufacturing process. These regulations are applied to any premises which discharge or release industrial effluent or mixed effluent. Under these regulations, the premises involved shall design and construct the Industrial Effluent Treatment System (IETS). They also have to comply with the wastewater regulations which include Environmental Quality (Schedules Waste) 2005 and Environmental Quality (Clean Air) Regulation 2014. In 2016, the DOE introduced Guided Self-Regulation (GSR), a self-regulated enforcement that allows factories to guide the regulation themselves. According to the GSR, the wastewater plants need to look out for eight components, namely Environment Policy, Competent Person, Environment Management and Decision Making Process Committee, Performance Monitoring Facilities and Instruments, Record Keeping, Data Analysis and Interpretation, Reporting and Communication as well as the Continuous Improvement. For any noncompliance, a "Field Citation" is issued and subsequently, the factory will receive a DOE Order Notification. Legal action will be taken by the government if the factory failed to comply with the Order Notification.

\section{Research Methodology}

In this study, an in-depth interview technique was utilized as the main instrument of primary data collection. It was also supported by the observation of $\mathrm{pH}$ level for the different types of beverage productions. The frequency of observation was five times a week and the duration of each observation was between 10 to 20 minutes. From the observation, 
interview session with respondents selected through purposive sampling was used as a method to gather information. The preference in using purposive sampling was because the type of sampling is limited to specialized individuals who are directly involved in the process and thus, will provide accurate information to meet the objective of this study.

As shown in Figure 1, the respondents represented employees of multiple positions, such as the executive and operator from wastewater treatment plant department (WWTP), manager and planner from production department and manager from warehouse department. These respondents have had vast experience in handling wastewater issue.

Fig 1: Respondent Profile

\begin{tabular}{llll}
\hline Respondent & Department & Position & Years of Experience \\
\hline 1 & WWTP & Executive & 3 \\
2 & Production & Manager & 20 \\
3 & Production & Planner & 6 \\
4 & WWTP & Operator & 2 \\
5 & WWTP & Executive & 3 \\
\hline \hline
\end{tabular}

\section{Findings}

\section{Factors contributing to the quality of wastewater}

Materials used for beverage production

Based on the interviewed session with all respondents, all of the respondents agreed that the quality of wastewater depends on the type of beverages production. The different types of production require different types of raw materials used for the production. For example, the production of coconut beverages requires coconut extract and ice lemon tea requires the lemon and tea as raw materials. Figure 2 shows the $\mathrm{pH}$ level reading for different types of beverage productions. This $\mathrm{pH}$ level reading was recorded for six cycles of production.

Fig. 2: $\mathrm{pH}$ level reading

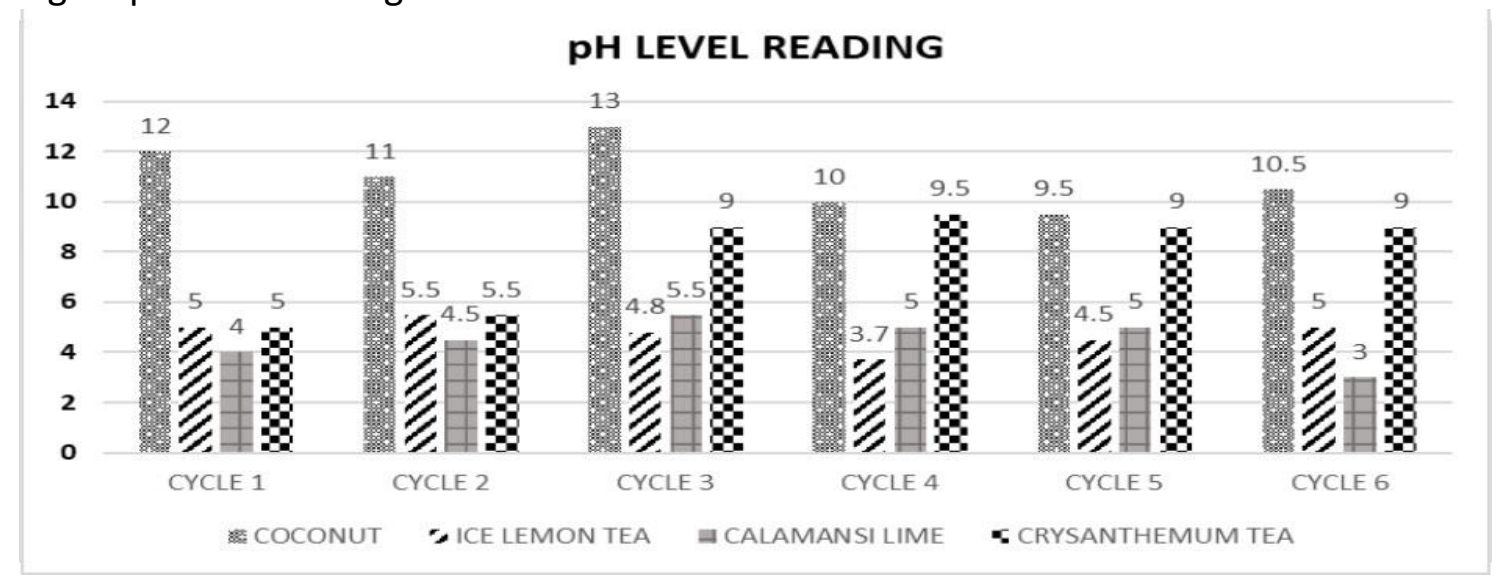

From the above graph, it is shown that the coconut beverage production contributes higher $\mathrm{pH}$ reading compared to other types of beverages. The range for final discharge of the treat water is from pH5.5 to pH9.0 based on standards given by Department of Environment (DOE). The discharge of waste water should be within the upper and lower limit line. If the discharge is lesser than the range, it does not meet the requirements given. The discharge point is the downstream of water abstraction points, therefore they are complying in 
accordance to Fifth Schedule [Sub regulation 11(1), 11(2), 11(3)], which is Acceptable Conditions for Discharge of Industrial Effluent or Mixed Effluent of Standards A and B (Standard B) stipulated in Environmental Quality (Industrial Effluent) Regulations 2009. According to the Respondent 1 , the coconut ingredient itself caused the effluent in the tank to be cloudy, smelly and looked dirty on top of the water. The coir of coconut can affect the treatment plant because during the production of coconut beverage, there were many coconuts used. Respondent 4 also said that among many productions, it is hard to control the quality of waste water in the treatment plant of coconut processing because they are using the natural ingredient itself. They took three to four days to clean the equipment and the plant from the coir of the coconut. Furthermore, the diameter of the tank is quite big for the workers to clear all the dirt before they start running the plant again on the next day.

\section{Method of $\mathrm{pH}$ reading}

Second factor that leads to the quality of the waste water is reading of the $\mathrm{pH}$ through either digital reading system or manual reading using a litmus paper. Sometimes the reading of the $\mathrm{pH}$ by digital reading system and litmus paper are not synchronized because of the longer time taken for the water inflow from one chemical tank to another chemical tank. Respondent 1 and 2 said that it can be controlled if the handheld $\mathrm{pH}$ meter in the chemical tank is always washed once or twice a week depending on the production. Frequent cleaning ensures accuracy and maintains effectiveness during measurement. The handheld $\mathrm{pH}$ meter should always be cleaned to prevent the build-up of dirt and floc on the glass bulb that may cause errors in measurement. It is important to remove all residues so that measurement is accurate. In addition, the cleanliness of $\mathrm{pH}$ meter in the chemical tank depends on the production. For instance, coconut can affect the quality of the wastewater in the WWTP with the buildup or coating of dirt or chemical process residues on the glass bulb. Coconut processing causes the $\mathrm{pH}$ of the wastewater to increase and the wastewater becomes unclear and brownish in colour since the coconut oil is too oily and hard to be cleaned up. Usually Respondent 4 takes between three to four days to clean it all up and make the tank clear again because of the coconut oil from coconut processing.

\section{Manpower}

The insufficient manpower in the waste water treatment plant (WWTP) contributes to the quality of wastewater because the treatment plant needs to be controlled and monitored every hour. The monitoring process is required for every hour to ensure the chemical used in treatment plant is in stable $\mathrm{pH}$ level. The insufficient workers situation happens when one worker is not only attached to a single department but also needs to be in the other department such as production department, so the workers cannot concentrate on one job as they need to multitask. In addition, to handle the treatment plant, it requires a worker who has a good background in chemical. Respondent 2 faced difficulties in recruiting new workers for WWTP department because it will take a long time to learn something new especially when it comes to chemicals. When the treatment plant is not monitored regularly, the maintenance of the machine cannot be done on time and therefore, the tendency of dirt or sludge to stick around the machine is higher and will affect the quality of wastewater.

\section{Machine and equipment}

The numbers of machine and equipment used in the plant to process wastewater are very limited. Therefore, only one machine is operated to process the wastewater. According to 
Respondent 2, even if new machines and equipment are added in the plant, they are still facing a problem in hiring a new worker who has experience, skills and knowledge to operate the new machine. Previously, the company tried using biological tank for treatment of wastewater to minimize the usage of chemical in the treatment process; however, according to Respondent 1 and Respondent 2, the tank did not function properly and caused the process of microorganisms and bacteria to grow rapidly which led to the inconsistency of $\mathrm{pH}$ level. Due to the said problem, the additional cost in hiring a third party to inspect and check the biological tanks was incurred and also affected the time taken to complete the wastewater process because the operation needed to be stopped while the inspection was being done. Therefore, the use of biological tank was terminated before it could get worse.

The effect of wastewater

Figure 3 shows the three effects of wastewater. All respondents agreed that the wastewater give impacts towards the environment, society and compliance to the law and regulations.

Fig. 3: $\mathrm{pH}$ level reading

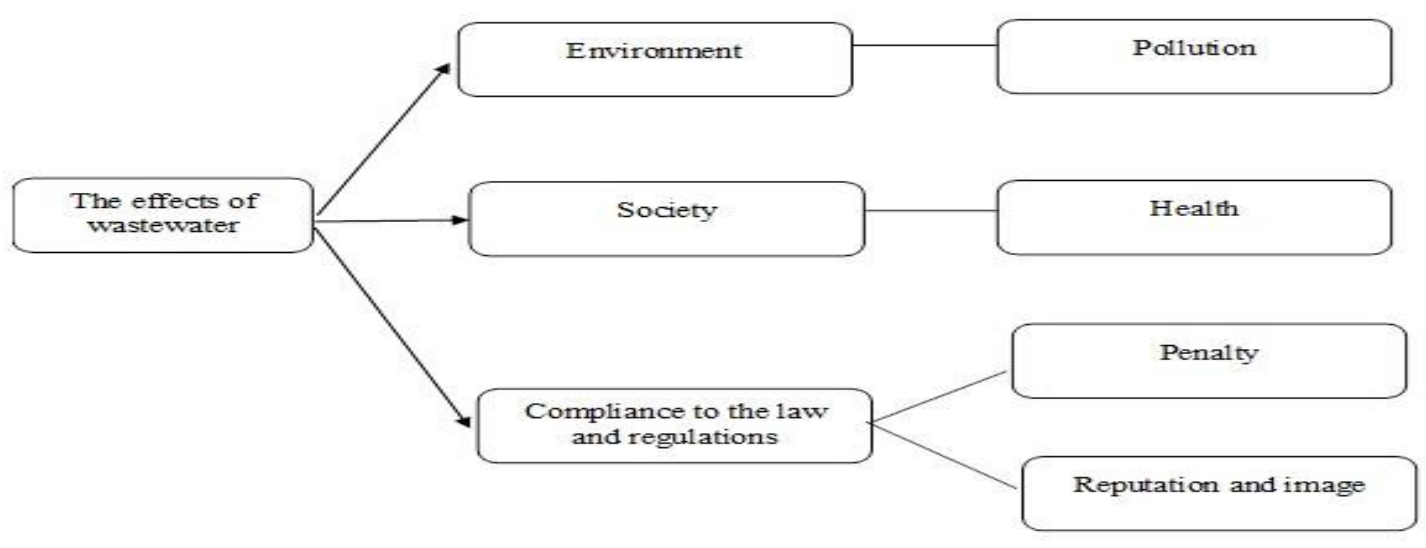

The impact of wastewater towards environment is water pollution as it contains unsafe chemical to the environment and it will affect the river quality as a whole. To achieve unpolluted wastewater discharge into receiving water bodies, careful planning, adequate and suitable treatment, regular monitoring and appropriate legislations are necessary (Akpor and Muchie, 2011). Wastewater can be a serious threat to the environment and human health (Khanpae, Karami, Maleksaeidi and Keshavarz, 2020). Such wastewater, if discharged without proper treatment, can severely pollute receiving water bodies and disrupt ecosystem completely (Shete and Shinkar, 2013). Jasim and Aziz, (2020) stated that the purpose of wastewater treatment is to remove or reduce contaminants in water that impose threats to human and environment if discharged to surface and/or ground waters without proper treatment. The consequences from this situation cause the shrinking of source of clean water for population consumption. Preserving the environment, and in particular tackling the problem of water pollution, has become a major preoccupation for everyonethe public, industry, scientists and researchers as well as decision-makers on a national European, or international level (Crini and Lichtfouse, 2019).

Impact of wastewater can also be directed towards society and people's health. Khanpae et al, (2020) mentioned in their studies that irrigation of wastewater can threaten human health because it contains bacteria, viruses and parasites. Wastewater contains pathogenic 
microorganisms such as viruses, bacteria and parasites which have the potential to cause diseases and impact human health (Hanjra, Blackwell, Carr, Zhang, and Jackson, 2012). The effects of wastewater towards health is not only for short term as if it is not managed well, it can also lead to long term effects on health such as cancer. In order to comply with wastewater legislations and guidelines, there is a need for adequate treatment before discharging the wastewater. This can be achieved through the application of appropriate treatment processes, which will help to minimise the risks towards public health and the environment. (Akpor and Muchie, 2011).

The last effect of wastewater is on the compliance to the law and regulations. According to Malaysia's Environmental Law, Environmental Quality Act, 1974, the Malaysia Environmental Quality (Sewage and Industrial Effluents) Regulations, 1979, 1999, 2000: Parameter Limits of Effluent of Standards A and B, the pH value should be 6.0-9.0 for standard A and 5.5-9.0 for Standard B. The consequence for not complying with this standard will lead to penalty charge for the company. The penalty is not only in terms of a fine but also imprisonment or worse, both. Furthermore, the company operations will be ceased until the issue is solved and eventually will contribute the delay in production and loss of business profit. The incompliance with the law and regulations brings negative impact to the company's image and reputation in the industry. The shareholder of the company would be upset with the company performance and it may also hinder potential investors from investing in the company business. Therefore, from the interview session with all respondents, all of them agreed that if the company is unable to manage the wastewater effectively, there will be more negative effects to the business in the future.

\section{Conclusion}

This study identified the factors contributing to the $\mathrm{pH}$ quality of wastewater. The main factor identified by the researcher is types of production of which different types of product require different raw materials. Coconut beverage has been identified as a product that contributes to high $\mathrm{pH}$ level due to its coir being used as part of the ingredients. Other than that, methods of reading $\mathrm{pH}$ level can be different by using either digital reading or manually using litmus paper. This happens because when the tank is not properly cleaned and maintained by the workers, the sludge formed will affect the digital reading. Therefore, manual reading using litmus paper is needed to confirm the $\mathrm{pH}$ level for the wastewater. The researcher also discovered that insufficient number of workers to handle wastewater treatment plant is one of the reasons that affects the $\mathrm{pH}$ quality. One worker does not only handle the wastewater issue but also needs to manage others production process. Based on the interview session, the difficulties in hiring new workers which are familiar and experienced in using the chemicals also contributes to the issue. The insufficient workers situation leads to machine not being thoroughly monitored and cleaned regularly to maintain the quality of wastewater. Even though the company have different types of production, it only uses one machine and same equipment in processing the wastewater. The same machine needs to handle all wastewater from different production. This issue raises the concern of the lack of machine monitoring and regular cleaning process which then leads to poor $\mathrm{pH}$ level that does not meet the standard guidelines by DOE.

Wastewater is basically affecting the environment, society and compliance to the law and regulations. Water pollution contains unsafe chemicals for the environment and it results to 
the shrinking of clean water source for population consumption. Impact of wastewater also can be directed towards society and health which is not only for the short term but if it is not well managed, it may also lead to long term effects towards health such as cancer. In order to comply with wastewater legislations and guidelines, there is a need for adequate treatment before the discharge of wastewater. The last effect of wastewater is on the compliance to the law and regulations. The consequences of not complying with this standard will lead to penalty charge for the company and the company operations may be ceased until the issue is solved. This will eventually contribute to other consequences such as delay in productions and loss of business profit.

This study helps the company to comply with DOE's $\mathrm{pH}$ level requirements within a range of between pH5.5 to pH9.5. The company understands more about the pattern of water discharge based on product types which assists the company in taking necessary action to control the wastewater discharge, especially when involved with coconut drink production. the correct $\mathrm{pH}$ reading of wastewater discharge contribute to a better environment for public and at the same time reduce the water pollution. this situation also contribute to the sustainability of environment as what United Nation (UN) facts shows that more than 80 percent of wastewater resulting from human activities is discharged into rivers or sea without any pollution removal and by year 2030 improve the water quality by reducing pollution, eliminating dumping, and minimizing release of hazardous chemicals and materials, half proportion of untreated wastewater and substantially increase recycling and safe reuse globally (UNDP, 2015).

\section{References}

Akpor, O., \& Muchie, M. (2011). Challenges in meeting the MDGs: The Nigerian drinking water supply and distribution sector. Journal of Environmental Science and Technology, 4(5), 480-489.

Connor, R. (2015). The United Nations world water development report 2015: Water for a sustainable world. UNESCO Publishing.

Crini, G., \& Lichtfouse, E. (2019). Advantages and disadvantages of techniques used for wastewater treatment. Environmental Chemistry Letters, 17(1), 145-155.

Edokpayi, J. N., Odiyo, J. O., \& Durowoju, O. S. (2017). Impact of wastewater on surface water quality in developing countries: A case study of South Africa. Water Quality.

Hanjra, M. A., Blackwell, J., Carr, G., Zhang, F., \& Jackson, T. M. (2012). Wastewater irrigation and environmental health: Implications for water governance and public policy. International Journal of Hygiene and Environmental Health, 215(3), 255-269.

Haseena, M., Malik, F. M., Javed, A., Arshad, S., Asif, N., Zulfiqar, S., \& Hanif, J. (2017). Water pollution and human health. Environmental Risk Assessment and Remediation, 01(03). Jasim, N. A., \& Aziz, H. A. (2020). The design for wastewater treatment plant (WWTP) with GPS X modelling. Cogent Engineering, 7(1), 1723782.

Khanpae, M., Karami, E., Maleksaeidi, H., \& Keshavarz, M. (2020). Farmers' attitude towards using treated wastewater for irrigation: The question of sustainability. Journal of Cleaner Production, 243, 118541.

Lofrano, G., \& Brown, J. (2010). Wastewater management through the ages: A history of mankind. Science of The Total Environment, 408(22), 5254-5264.

Rinkesh, K. (2019). The effects of wastewater on the environment. Conserve Energy Future. 
Shete, M. B. (2013). Comparative study of various treatments for dairy industry wastewater. IOSR Journal of Engineering, 03(08), 42-47.

United Nations Development Programme (UNDP), Sustainable Development Goals. (2015) Retrieved May 04, 2021, from https://www.un.org/sustainabledevelopment/sustainable-development-goals/

Valta, K., Kosanovic, T., Malamis, D., Moustakas, K., \& Loizidou, M. (2015). Overview of water usage and wastewater management in the food and beverage industry. Desalination and Water Treatment, 53(12), 3335-3347.

Villarín, M. C., \& Merel, S. (2020). Paradigm shifts and current challenges in wastewater management. Journal of Hazardous Materials, 390, 122139. 